\title{
ENVIRONMENTAL CONTAMINATION BY Toxocara spp. EGGS IN A RURAL SETTLEMENT IN BRAZIL
}

\author{
Vamilton Alvares SANTARÉM(1), Elisabeth da Cunha FRANCO(2), Fernanda Torres KOZUKI(2), Danila FINI(2) \& Luiz Euribel PRESTES-CARNEIRO(3)
}

\begin{abstract}
SUMMARY
In order to study the environmental contamination by Toxocara spp. eggs in a rural community from the Pontal do Paranapanema region, São Paulo State, Brazil, soil samples from 31 out of 121 plots were collected in eight different places on each house. The samples were submitted to flotation technique in sodium nitrate $\left(\mathrm{d}=1.20 \mathrm{~g} / \mathrm{cm}^{3}\right)$. Eggs of Toxocara spp. were recovered in nine $(29.03 \%)$ out of the 31 plots. At least one dog was registered in 27 of the 31 plots examined (87.1\%) and at least one cat in $17(54.84 \%)$. The number of pets per plot ranged from one to six (mean of 2.3) for dogs and one to 14 (mean of 1.29) for cats. In 16 plots (51.61\%), the presence of both dogs and cats was observed. There was no relation between the presence of pets in the plots and soil contamination ( $p>0.05$ ). However, the environmental contamination by Toxocara spp. eggs associated to the poor conditions of the inhabitants may be an important risk factor for the human population to ocular or visceral larva migrans.
\end{abstract}

KEYWORDS: Toxocariasis; Larva migrans; Soil contamination; Rural community.

\section{INTRODUCTION}

Toxocara canis and Toxocara cati are saprozoonotic parasites of dogs and cats, respectively, capable of infecting man and causing toxocariasis. Infection of human beings is caused by ingestion of embryonated eggs containing L2 larvae, especially $T$. canis, by hand-to-mouth contact ${ }^{1}$. The infective larvae hatch, penetrate the intestinal wall, migrate through the soft tissues of the body, and may result in either ocular or visceral larva migrans ${ }^{7}$.

Human toxocariasis is probably one of the widest spread zoonotic nematode infections, and it is considered one of the most prevalent helminthiasis in industrialized countries ${ }^{10}$. However, it has been underestimated and can be considered as a neglected disease.

The main source of human infection is considered to be environmental contamination by Toxocara spp. eggs, especially in public areas of large urban centers, such as parks and gardens frequented by dogs and cats as well as humans ${ }^{1}$. In Brazil, studies have been done pointing out the contamination of public places by Toxocara spp. eggs $^{3,4,11,16}$. Also, the epidemiology of toxocariasis in different regions has been studied. An association between the higher frequency of seroreactivity to $T$. canis antibodies in humans and socioeconomic variables such as educational level, family income, water treatment ${ }^{2}$ and contact with soil ${ }^{5,6}$, with a predominance of seropositivity in children, has been observed.

São Paulo, located in Southeast of Brazil, is considered the richest state of the country. Conversely, Pontal do Paranapanema, in the western region, is one of the poorest and undeveloped regions of the state, and is characterized by large cattle-raising farms. Since 1982, the landless population has increased dramatically because of increased pressure over land owners, and has resulted in highest number of landless squatters and settlements in Brazil ${ }^{14}$. The increasing number of people living in the settlements, often in plastic-hut located on marginal lands or next to highways near cattle raising areas and water sources, with poorresources and precarious living conditions, inadequate sanitary care and sanitary education, associated to presence of pets, represents an important source of environmental contamination by parasites, which may favor the establishment of the biologic life cycle of parasites such as Toxocara spp.

In a rural settlement (Padre Josimo), at the same area, a frequency of $21.5 \%$ of Toxocara spp. antibodies in the human population was observed. When soil samples were checked in 24 plots where at least one human being was considered seropositive, embryonated Toxocara spp. eggs were found in five $(21 \%)$ of the investigated plots $^{15}$.

The purpose of the present study was to determine the frequency of Toxocara spp. contamination in soil and aspects regarding its transmission in a rural community population in São Paulo, Brazil.

\section{MATERIALS AND METHODS}

Study area: The study was carried out in the settlement Água Sumida, located in Teodoro Sampaio ( $22^{\circ} 17^{\prime} 12^{\prime \prime}$ S; 52 $\left.2^{0} 36^{\prime} 12^{\prime \prime} \mathrm{W}\right)$, west

(1) Curso de Graduação em Medicina Veterinária e Mestrado em Ciência Animal - Universidade do Oeste Paulista (Unoeste), Presidente Prudente, São Paulo, Brazil.

(2) Veterinarians.

(3) Depto. de Imunologia e Pós-Graduação e Pesquisa, Unoeste.

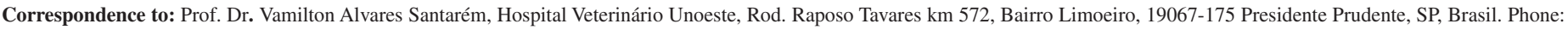
55.18 32292066; FAX: 55.18.32292034. E-mail: vamilton@ unoeste.br 


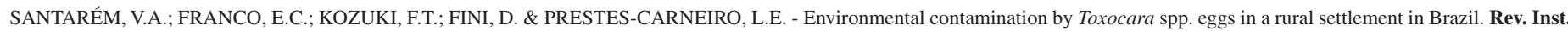
Med. trop. S. Paulo, 50(5): 279-281, 2008.

region of São Paulo State, Brazil. It is an area occupied by the "Landless Peasants Movement" (MST) since 2000, and it was expropriated in 2003 for land reform purposes by the Brazilian National Institute for Land, Settlement and Agrarian Reform (INCRA). The settlement comprises 4,210.64 hectares, and since 1988 has been divided into 121 plots $^{9}$. Most of the inhabitants lived in small brick-built houses.

With a tropical climate, followed by a rainy season in the summer, the region has a dry weather in the winter with a sandy top-soil mostly meant for pastures and cattle raising, with temperatures ranging from $28{ }^{\circ} \mathrm{C}$ to $36^{\circ} \mathrm{C}$ in the summer. The municipality of Teodoro Sampaio had 19,992 inhabitants in 1999, with $56.7 \%$ of them living in a high level of social vulnerability, according to the Brazilian Institute of Geography and Statistics ${ }^{8}$.

Period and collection of the samples: From May to October, 2006, soil samples were collected from 31 out of 121 plots (25.62\%), chosen by systematic sampling, based on an arithmetic progression of the number of plots ${ }^{17}$. In the case where the plots were uninhabited, the neighboring plot was included in the study.

The soil sample was collected in eight different sites surrounding the residence of the settled inhabitants (two in front of the house, two in each lateral, and two from the back). About $50 \mathrm{~g}$ of soil was removed down to 5 $\mathrm{cm}$ in depth at each site, resulting in eight samples by plot. The samples were separately carried to the laboratory in a polyethylene bag.

As a precaution, after eliminating the superficial dirt, a minimum distance of two meters was established for soil collection, whenever feces were visible.

Processing of the soil samples: The samples were stocked in brand new plastic bags and refrigerated until processed. Two aliquots of $10 \mathrm{~g}$ from the material of each side of the house, after homogenization, was weighed, washed with a $0.2 \%$ Tween- 80 solution, and transferred to a sedimentation receptacle where they were left overnight at room temperature. The supernatant was discarded and the sediment was washed with a decinormal sodium hydroxide, and was resuspended in a sodium nitrate solution, specific gravity $1.20 / \mathrm{cm}^{3}$. The recovery of Toxocara spp. eggs was repeated three times for each aliquot.

Data collection: A questionnaire was directed in order to collect data on the number of inhabitants by plot and the number of pets, including gender and the age of the animals.

Statistical analysis: Statistical analysis was performed with a statistical package using Chi-square test. P-values lower than 0.05 was considered to be statistically significant ${ }^{18}$.

\section{RESULTS}

Eggs of Toxocara spp. were recovered in nine (29.03\%) out of the 31 plots examined. The number of eggs varied from two to four. In five of the studied plots (16.2\%), the eggs presented characteristics of viability, with moving larvae inside the eggs observed in three different plots, and immovable larvae in other two. The presence of eggs was observed in all of the sites surrounding the plots $(46.15 \%$ in the lateral area; $38.46 \%$ in front of the house and $15.39 \%$ in the backyard).
A population of 85 inhabitants in the visited plots was registered (mean of 2.29/plot). A total of 76 dogs and 42 cats were observed, and the number of animals per plot ranged from one to six (mean of 2.3) for dogs, and from one to 14 (mean of 1.29) for cats. There was at least one dog or cat in 27 and 17 out of the 31 plots visited, respectively. In $16(51.61 \%)$ out of the 31 households in our study area have both dogs and cats. Puppies were observed in three plots $(0.09 \%)$, and in only one plot (0.03) a kitten was verified. A 1:1.12 dog/human and 1:2.02 feline/ human proportion was observed.

The presence of pets was verified in $23 \%$ of contaminated plots and in $58 \%$ of non-contaminated ones. There was no association between the presence of animals in the plots and soil contamination by Toxocara spp. eggs $(p=0.7961)$. In two out of nine $(6.0 \%)$ contaminated plots, neither dogs nor cats were registered.

\section{DISCUSSION}

The aim of this study was to analyze the environmental contamination by Toxocara spp. eggs from settled communities in rural areas of São Paulo State, Brazil.

The frequency of soil contamination $(29.03 \%)$ observed in the settlement Água Sumida was higher than the one observed in the settlement Pe. Josimo in the same area ${ }^{15}$. However, the soil contamination was evaluated by these authors in plots where at least one inhabitant had shown anti-Toxocara spp. antibodies.

The contamination in the rural community studied was also higher than the verified in public areas from other cities in São Paulo State, such as Botucatu ${ }^{16}$ and Ribeirão Preto ${ }^{3}$, where the reported contamination was $17.5 \%$ and $20.5 \%$, respectively. However, in Sorocaba, contamination occurred in $53.3 \%$ of the samples examined, besides being an urban $\operatorname{area}^{5}$. Several factors may contribute to this variation, such as climatic and environmental conditions, the density of dogs and cats in the areas ${ }^{11}$, texture of the soil analyzed, and diagnostic methodology employed ${ }^{12}$. In this study, we adopted a solution of sodium nitrate, which was considered the most efficient to recovery Toxocara spp. eggs when compared to sodium chloride, magnesium sulphate, and zinc sulphate solutions ${ }^{13}$.

It would be expected a soil contamination by Toxocara vitulorum, ascaridoid species that parasites ruminants, once cattle are raised in these rural settlements. However, according to the inhabitants, access of cattle was not allowed in the area around the house, where the samples were collected. Consequently, this information supported the recovered Toxocara spp. eggs might had been shed by dogs and/or cats.

Although a poor vegetation and dry soil was observed in some plots, which could cause quick disintegration of the eggs, the recovery of embryonated Toxocara spp. eggs $(16.2 \%)$ indicates that the environmental conditions were favorable to their development.

Although the number of puppies and kittens was lower than the population of adult pets in the studied settlement, there were evidences of poor hygiene and bad nutrition conditions of pets while collecting samples, that usually defecate in pens surrounding the house and, consequently, maintaining a highly contaminated habitat. Even pets that had been considered domicilied by their owners, presented the behavior of 
stray animals, having free access to the neighboring plots. It is reasonable to assume that contamination of soil would be heavier if these pets were restrained to their own plots.

In this study, no association was observed between soil contamination and the presence of pets in the plots. However, it is not possible to exclude that these animals can play an important role in epidemiology of toxocariasis, representing a risk factor to the human infection by hand-to-mouth contact.

Pet population density in settlement and the soil contamination by Toxocara spp. eggs should be considered while elaborating an appropriate education, control and prevention program of human toxocariasis for those areas.

\section{RESUMO}

\section{Contaminação ambiental por ovos de Toxocara spp. em assentamento rural no Brasil}

Com o objetivo de avaliar a contaminação ambiental por ovos de Toxocara spp. em assentamento rural da região do Pontal do Paranapanema, oeste do estado de São Paulo, Brasil, amostras de solo de oito diferentes pontos ao redor da casa de 31 dos 121 lotes do assentamento foram coletados. A recuperação de ovos foi realizada pela técnica de centrífugo-flutuação em solução de nitrato de sódio $(\mathrm{d}=1,20 \mathrm{~g} /$ $\left.\mathrm{cm}^{3}\right)$. Ovos de Toxocara spp. foram recuperados em nove $(29,03 \%)$ dos 31 lotes. Em 27 das 31 casas amostradas $(87,1 \%)$, havia pelo menos um cão e em $17(54,84 \%)$ pelo menos um gato. O número de cães por lote variou de um a seis (media de 2,3). No caso dos gatos, o número variou de um a 14 (média de 1,29). Em 16 dos 31 lotes $(51,61 \%)$, havia a presença de pelo menos um cão ou gato. Não houve relação entre a presença desses animais e a contaminação do solo $(p>0,05)$. Entretanto, a contaminação do solo por ovos de Toxocara spp. e as precárias condições de higiene tanto da população quanto dos seus animais compõem um ambiente favorável à infecção dos assentados por agentes de larva migrans/toxocaríase.

\section{ACKNOWLEDGEMENTS}

To Fundação de Amparo à Pesquisa do Estado de São Paulo (FAPESP) by the fellowship to Elisabeth da Cunha Franco (Process number 05/59426-0).

\section{REFERENCES}

1. ACHA, P. \& SZYFRES, B. - Zoonosis y enfermedades transmissibles al hombre y a los animales. 2. ed. Washington, Organización Panamericana de la Salud, 1986.

2. ANARUMA FILHO, F.; CHIEFFI, P.P.; CORREA, C.R.S. et al. - Human toxocariasis: a seroepidemiological survey in the municipality of Campinas (SP), Brazil. Rev. Inst. Med. trop. S. Paulo., 44: 303-307, 2002.

3. CAPUANO, D.M. \& ROCHA, G.M. - Environmental contamination by Toxocara sp eggs in Ribeirão Preto, São Paulo, Brazil. Rev. Inst. Med. trop. S. Paulo., 47: 223-226, 2005 .
4. CHIEFFI, P.P. \& MULLER, E.E. - Prevalência de parasitismo por Toxocara canis em cães e presença de ovos de Toxocara sp no solo de localidades públicas da zona urbana do município de Londrina, Estado do Paraná, Brasil. Rev. Saúde publ. (S. Paulo), 10: $367-372,1976$.

5. COELHO, L.M.P.S.; DINI, C.Y.; MILMAN, M.H.S.A. \& OLIVEIRA, S.M. -Toxocara spp. eggs in public squares of Sorocaba, São Paulo State, Brazil. Rev. Inst. Med. trop. S. Paulo, 43: 189-191, 2001.

6. FIGUEIREDO, S.D.P.; TADDEI, J.A.A.C.; MENEZES, J.J.C. et al. - Clinicalepidemiological study of toxocariasis in a pediatric population. J. Pediat. (Rio de J.), 81: 126-132, 2005

7. GLICKMAN, L.T. \& SCHANTZ, P.M. - Epidemiology and pathogenesis of zoonotic toxocariasis. Epidem. Rev., 3: 230-250, 1981.

8. IBGE. Instituto Brasileiro de Geografia e Estatística - 2000 Censo Demográfico Teodoro Sampaio. Available: http://www.seade.gov.br/produtos/ipvs/analises/teodosampaio. pdf. Accessed in: 28 October 2005.

9. ITESP - Instituto de Terras do Estado de São Paulo José Gomes da Silva. 2005. Available http://www.justica.sppgov.br/Itesp/Assentamentos.htm. Accessed in: 28 October 2005

10. MAGNAVAL, J.F.; GLICKMAN, L.T.; DORCHIES, P. \& MORASSIN, B. - Highlights of human toxocariasis. Korean J. Parasit., 39: 1-11, 2001.

11. MURADIAN, V.; GENNARI, S.M.; GLICKMAN, L.T. \& PINHEIRO, S.R. -Epidemiological aspects of Visceral Larva Migrans in children living at São Remo Community, São Paulo (SP), Brazil. Vet. Parasit., 134: 93-97, 2005.

12. NUNES, C.M., SINHORINI, I.L. \& OGASSAWARA, S. - Influence of soil texture in the recovery of Toxocara canis eggs by a flotation method. Vet. Parasit., 53: 269-274, 1994

13. OGE, H. \& OGE, S. - Quantitative comparison of various methods for detecting eggs of Toxocara canis in samples of sand. Vet. Parasit., 92: 75-79, 2000.

14. PRESTES-CARNEIRO, L.E.; FREITAS, S.B.; ZAGO, S.C. et al. - Taeniasis-cysticercosis complex in individuals of a peasants' settlement (Teodoro Sampaio, Pontal of Paranapanema, SP, Brazil. Mem. Inst. Oswaldo Cruz., 101: 15-20, 2006.

15. PRESTES-CARNEIRO, L.E.; SANTARÉM, V.A.; ZAGO, C.S. et al. - Sero-epidemiology of toxocariasis in a rural settlement in São Paulo state, Brazil. Ann. trop. Med. Parasit., 102: 347-356, 2008.

16. SANTARÉM, V.A.; SARTOR, I.F. \& BERGAMO, F.M.M. - Contaminação, por ovos de Toxocara spp, de parques e praças públicas de Botucatu, São Paulo, Brasil. Rev. Soc. bras. Med. trop., 31: 529-532, 1998.

17. TORRES, T.Z.G. - Amostragem. In: MEDRONHO, R.A.; CARVALHO, D.M.; BLOCH, K.V.; LUIZ, R.R. \& WERNECK, G.L., ed. Epidemiologia. São Paulo, Atheneu, 2002. p. 283-294.

18. TRIOLA, M.F. - Introdução à estatística. 7.ed. Rio de Janeiro, LTC, 1999.

Received: 23 October 2007

Accepted: 15 September 2008 